\title{
Retrofitting Air Conditioning and Duct Systems in Hot, Dry Climates
}

C. Shapiro, R. Aldrich, and L. Arena Consortium for Advanced Residential Buildings (CARB) 


\begin{abstract}
NOTICE
This report was prepared as an account of work sponsored by an agency of the United States government. Neither the United States government nor any agency thereof, nor any of their employees, subcontractors, or affiliated partners makes any warranty, express or implied, or assumes any legal liability or responsibility for the accuracy, completeness, or usefulness of any information, apparatus, product, or process disclosed, or represents that its use would not infringe privately owned rights. Reference herein to any specific commercial product, process, or service by trade name, trademark, manufacturer, or otherwise does not necessarily constitute or imply its endorsement, recommendation, or favoring by the United States government or any agency thereof. The views and opinions of authors expressed herein do not necessarily state or reflect those of the United States government or any agency thereof.
\end{abstract}

Available electronically at http://www.osti.gov/bridge

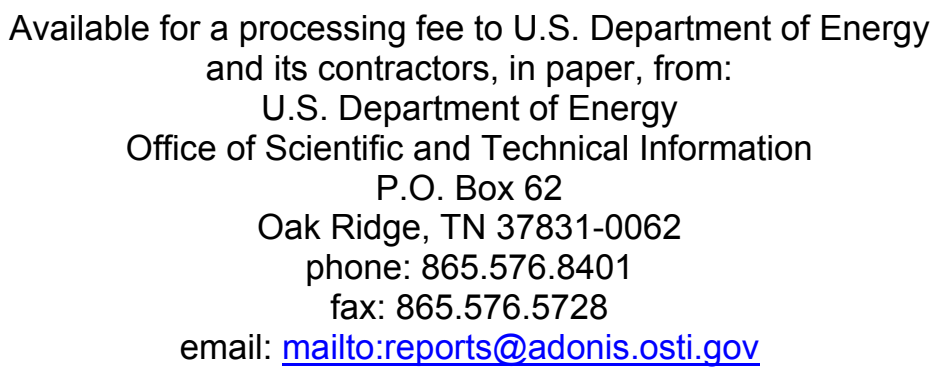

Available for sale to the public, in paper, from:

U.S. Department of Commerce

National Technical Information Service

5285 Port Royal Road

Springfield, VA 22161

phone: 800.553 .6847

fax: 703.605 .6900

email: orders@ntis.fedworld.gov

online ordering: http://www.ntis.gov/ordering.htm

Printed on paper containing at least $50 \%$ wastepaper, including $20 \%$ postconsumer waste 


\title{
Retrofitting Air Conditioning and Duct Systems in Hot, Dry Climates
}

\author{
Prepared for: \\ Building America \\ Building Technologies Program \\ Office of Energy Efficiency and Renewable Energy \\ U.S. Department of Energy \\ Prepared by: \\ Carl Shapiro, Robb Aldrich, and Lois Arena \\ Steven Winter Associates, Inc. \\ of the Consortium for Advanced Residential Buildings (CARB) \\ 61 Washington Street \\ Norwalk, CT 06854 \\ NREL Technical Monitor: Cheryn Engebrecht \\ Prepared under Subcontract No. KNDJ-0-40342-02
}

July 2012 
[This page left blank] 


\section{Contents}

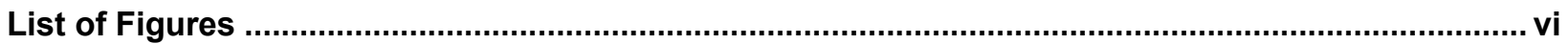

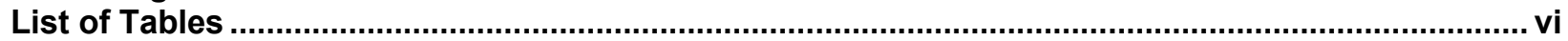

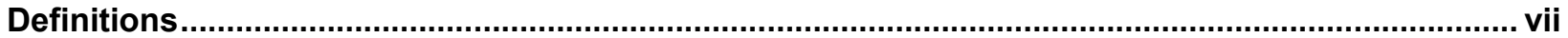

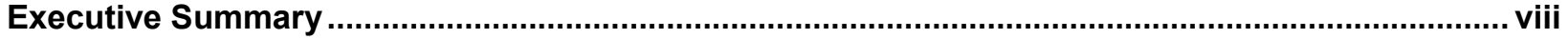

1 Introduction

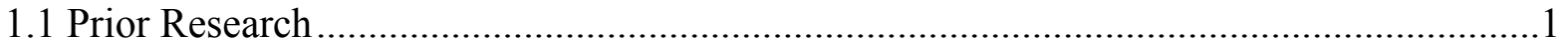

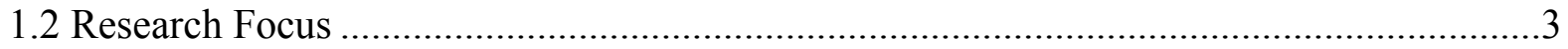

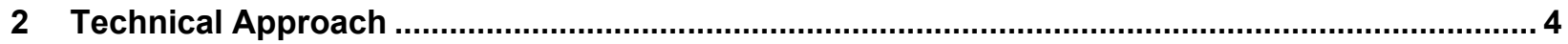

2.1 Portable EER Measurement System .........................................................................4

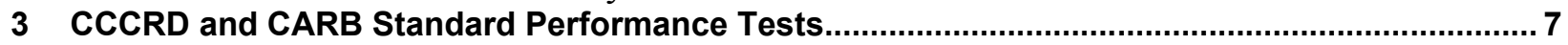

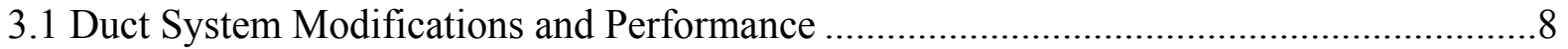

3.2 System Airflows and Static Pressures...................................................................... 9

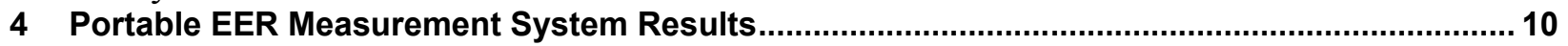

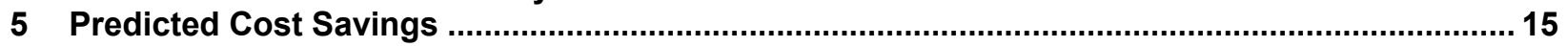

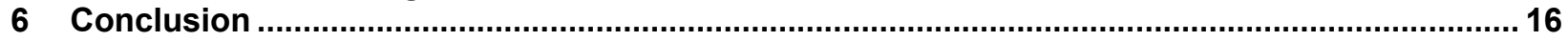

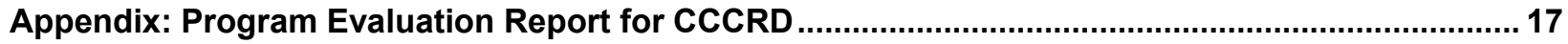

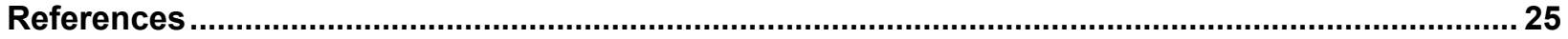




\section{List of Figures}

Figure 1. Example effects of flow rate on AC sensible capacity, latent capacity, and power consumption at constant indoor and outdoor conditions and static pressure differential. Numbers above data points refer to sensible EER (Sensible Btu/Wh)

Figure 2. EER portable test system suitcase without sensors ................................................... 5

Figure 3. Manufacturer listed and measured sensible capacity. CCCRD measured flow rate used for House 2.

Figure 4. Manufacturer listed sensible EER ….............................................................................. 14

Unless otherwise noted, all figures were created by CARB.

\section{List of Tables}

Table 1. Heating and Cooling System Type, Capacity, and Efficiency ............................................ 8

Table 2. Space Conditioning Equipment Model Numbers .................................................................... 8

Table 3. Duct System Airflow and Leakage (CCCRD Measurements) ............................................... 9

Table 4. System Airflows and Static Pressures ............................................................................ 10

Table 5. Coil Sizing and Impact on Slope of Sensible EER Improvement ........................................ 12

Table 6. Cost of Increased Sensible Cooling Efficiency Measures ..................................................... 15

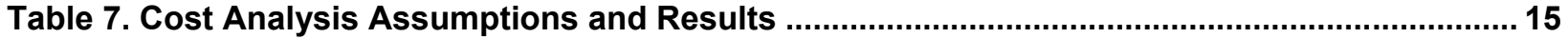

Unless otherwise noted, all tables were created by CARB. 


\section{Definitions}

AC

ACCA

AFUE

AHU

BPI

CARB

CCCRD

DHW

CFM

EER

HERS

HUD

HVAC

iwc

NSOP

NSP

RESNET

SEER

SHR

SNRHA

SWA air conditioning

Air Conditioning Contractors of America

annual fuel utilization efficiency

air handling unit

Building Performance Institute

Consortium for Advanced Residential Buildings

Clark County Community Resources Division

domestic hot water

cubic feet per minute

energy efficiency ratio

Home Energy Rating System

U.S. Department of Housing and Urban Development

heating, ventilation, and air conditioning

inch water column

normal system operating pressure

Neighborhood Stabilization Program

Residential Energy Services Network

seasonal energy efficiency ratio

sensible heat ratio

Southern Nevada Regional Housing Authority

Steven Winter Associates, Inc. 


\section{Executive Summary}

Since 2009, Clark County, Nevada, has received significant funding through the Neighborhood Stabilization Program (NSP), which is administered by the Department of Housing and Urban Development (HUD). The purpose of this funding was to stabilize communities that have suffered from foreclosures and abandonment. The Clark County Community Resources Division (CCCRD) has used these funds to purchase foreclosed properties, perform audits on the homes, and implement health, safety, and energy improvements to the properties. The renovated homes are rented or sold to qualifying buyers.

The Consortium for Advanced Residential Buildings (CARB) has worked with CCCRD over the past two years to help optimize renovations with respect to health, safety, energy performance, and cost. CARB has also assessed the training needs of contractors and auditors and has helped CCCRD implement appropriate trainings. Because air conditioning is the dominant load in Las Vegas, CARB has worked with CCCRD to develop procedures for upgrading cooling systems.

This report focuses on CCCRD's procedures for increasing sensible efficiencies through increased flow rates across the air handling unit and increased indoor coil sizes. Although higher flow rates often would not be possible with an existing duct system, CCCRD and CARB recognized that, when substantial energy improvements result in a significant reduction in design cooling loads, an older and constrictive duct system may allow higher flow rates (CFM/ton) when combined with replacing an older existing condensing unit with a smaller unit. In practice, however, auditors and contractors determined that existing duct systems needed replacement in most cases due to factors such as poor layout, damage, and improper design.

Detailed monitoring of five air conditioning systems provided valuable information about the success of CCCRD guidelines to increase sensible cooling efficiency. Three of the five homes met or exceeded CCCRD requirements for flow rate. Of the two homes that failed to meet the flow targets, one home had a packaged rooftop unit connected to ductwork that was never designed for flow rates greater than $400 \mathrm{CFM} /$ ton. Although issues with sensors used with the portable energy efficiency ratio (EER) measurement system precluded direct measurement of total system efficiency, the measured sensible capacity of the system met manufacturer ratings at the measured operating conditions. An examination of the manufacturer ratings shows that when indoor coils are oversized, the improvement in the sensible efficiency is more pronounced as airflows increase.

Since duct systems needed replacement in most cases for reasons unrelated with the increased flow rates, the cost associated with increasing flow rates across the air handling unit was minimal. The resulting utility bill savings of this measure, although small, are cost effective. The annualized rate of return of this measure was $6 \%$ to $32 \%$. 


\section{Introduction}

For more than two years, Nevada has suffered from the highest foreclosure rate in the nation, an unemployment rate that has reached almost $14 \%$, and a dramatic bursting of a housing bubble that has left most homes in the state worth less than half the purchase price (Medina 2011). To combat these economic woes, the Department of Housing and Urban Development (HUD) granted the state of Nevada almost \$40 million dollars in 2009 through the Neighborhood Stabilization Program (NSP), which aims to stabilize communities that have suffered from foreclosures and abandonment. In turn, Clark County, Nevada, which is the home of Las Vegas, received just over \$25 million in state and federal funding under the NSP.

Through the Clark County Community Resources Division (CCCRD), Clark County has developed a renovation program that uses NSP funding to: (1) purchase foreclosed properties; (2) perform audits to assess code compliance, energy efficiency, and health issues; (3) implement repairs recommended by the audits; and (4) resell the properties to qualifying buyers or transfer the properties to the Southern Nevada Regional Housing Authority (SNRHA) for rental. The most recent round of purchases and renovations, which are the focus of this report, were performed between 2010 and 2011. During this period, CCCRD performed renovationsincluding energy efficiency upgrades, health and safety repairs, cosmetic repairs, and improvements to bring homes into compliance with local codes - on 184 homes constructed between 1979 and 2007.

This report focuses on CCCRD's procedures for increasing sensible efficiencies through increased flow rates across the air handling unit and increased indoor coil sizes. Although higher flow rates often would not be possible with an existing duct system, CCCRD and CARB recognized that when substantial energy improvements result in a significant reduction in design cooling loads, an older and constrictive duct system may allow higher flow rates ( $\mathrm{CFM} /$ ton) when combined with replacing an existing condensing unit with a smaller unit. In practice, however, auditors and contractors determined that existing duct systems needed replacement in most cases due to factors such as poor layout, damage, and improper design.

\subsection{Prior Research}

Since January 2010, CARB has partnered with CCCRD to provide technical support and assistance toward meeting the energy efficiency goals of their NSP program, which include reducing the Home Energy Rating System (HERS) index of any home purchased under this program to less than 50 (lower values signify less energy usage). CARB has provided Clark County with:

1. Modeling assistance

2. Systems research with respect to attic insulation and mechanical ventilation

3. Support with performance testing

4. Ongoing technical assistance with heating, ventilation, and air conditioning (HVAC) design and quality installation of air conditioning (AC) and heat pump systems 
5. Practical guidelines in 2010 for Clark County remodelers to comply with Building Performance Institute (BPI) and Air Conditioning Contractors of America (ACCA) standards and other best practices (Arena 2010).

In 2011, CARB's support and evaluation of CCCRD's NSP program had two main aspects. First, CARB focused on evaluating the overall effectiveness of CCCRD's NSP program with respect to energy efficiency. Second, CARB evaluated the effectiveness of CCCRD's AC design standards, particularly with respect to air flow and duct reconfigurations. The former research was published as a report to CCCRD (see Appendix) and is summarized below, whereas the latter research is the primary focus of this report.

Through analysis of program documentation and data from 40 of the program's homes (representing approximately $22 \%$ of the program total), CARB evaluated the overall effectiveness of the energy efficiency measures implemented in the most recent round of renovations. This analysis determined the degree of energy savings, the difference between actual and estimated costs, and the energy savings potential of the program by house construction date.

In most cases, the final (test-out) average energy efficiency of each component met or exceeded the value recommended by the auditors. Based on the test-in and test-out results, the average utility bill savings for this sample is anticipated to be approximately $\$ 806$ per year, and the average HERS index improved from 121 to 69. Although CCCRD did not meet their goal of an average HERS index of 50, they succeeded in significantly reducing the energy usage of the purchased properties.

Costs were first analyzed broadly by major improvement category (i.e. energy efficiency, health and safety, and code/cosmetic) and then explored in more detail at the energy efficiency level. While actual costs were higher than estimated costs in each major category, the biggest differences were associated with code and cosmetic improvements. When comparing actual and estimated costs for the energy efficiency upgrades, the most significant differences were in the mechanical systems category. On average, the actual costs for mechanical system improvements (HVAC, domestic hot water (DHW), and mechanical ventilation combined) were $27 \%$ higher than the initial bids. Underbidding was the most apparent reason for this discrepancy, although many other factors may have contributed.

Mechanical contractors were unfamiliar with the amount of testing associated with installing HVAC systems to the standards required by Clark County, which come from ACCA's standards for quality installation of air conditioning equipment. ${ }^{1}$ While these standards should be standard practice for the industry, issues with compliance are rampant across the country. Performing design calculations and commissioning the systems once installed were tasks with which most HVAC contractors in the Las Vegas area were unfamiliar. Third party verification by BPI auditors and/or Residential Energy Services Network (RESNET) certified energy raters was

${ }^{1}$ See Arena (2010) for more details. Various technical manuals and standards give information about quality installation of air conditioning equipment (ACCA 2007, ACCA 2008, ACCA 2009a, ACCA 2009b, ASHRAE 2004, BPI 2003, CARB 2009, Hohman 2009, Hohman 2010, Krigger and Dorsi 2006, Krigger and Dorsi 2008, Moravek 2009, Rutkowski 1995, Rutkowski 2006). 
required on all projects, and initial inspections confirmed that commissioning and Manual $\mathbf{J}$ (Rutkowski 2006) calculations were not being properly performed on the vast majority of the houses. As a result, the auditors found themselves training the contractors on the proper methods and had to perform repeated inspections before the HVAC systems complied with BPI standards. Not understanding the associated requirements, contractors typically underbid the work and then regularly increased their prices during renovation.

\subsection{Research Focus}

Based on the program evaluation performed during the first half of 2011, CARB and CCCRD deemed CCCRD's efforts to optimize air conditioning and duct system retrofits to be the most pressing subject requiring further research. Air conditioning is typically the largest load in hot, dry climates like Las Vegas, and CCCRD has appropriately placed a large emphasis on AC efficiency and performance. The large discrepancy between bid and actual costs for mechanical system upgrades in CCCRD's NSP program, however, is a cause for concern, and given these higher costs, greater research is needed to ensure that CCCRD's exacting standards are producing results.

An important requirement CCCRD employs to produce higher AC efficiencies is a specification for larger indoor cooling coils and higher air handling unit (AHU) flow rates (400-480

$\mathrm{CFM} /$ ton). While many other factors, such as flow rate, liquid line restrictions, coil obstructions, refrigerate charge, and non-condensable matter in the refrigerant lines can affect performance, air flow rates and indoor coil size were the primary target of this research. Design manuals indicate that increasing airflow and indoor coil size will increase sensible capacity and decrease latent capacity (Rutkowski 1995, Rudd 2006). In hot, dry climates where large latent cooling loads generally do not exist, trading latent capacity for sensible capacity is often desirable.

Furthermore, the increased sensible cooling capacity is associated with a much smaller increase in power consumption, which is mostly caused by increased fan energy usage. As a result, effective sensible EER ratings are increased.

For example, the 3-ton split system shown in Figure 1 experiences an improvement in sensible efficiency of $9 \%$ when flow rate is increased from $363 \mathrm{CFM} /$ ton to $450 \mathrm{CFM} /$ ton. A review of various split system air conditioners indicates that increasing coil size by one unit size increases sensible cooling capacity and rated EER by $1 \%-2 \%$. The increase in sensible capacity for both measures is accomplished by essentially trading latent capacity for sensible capacity. In hot, dry climates, latent capacities are generally small and increased sensible capacities are desired. In hot, humid climates, the opposite is generally true, and latent capacities can be increased by reducing air flow rates per ton and reducing indoor coil size compared to the outdoor unit.

When retrofitting existing homes, however, achieving higher flow rates can be quite challenging. In many older homes, duct systems are very leaky and quite constrictive, meaning that the ducts are not large enough to handle larger AC flow rates. Higher flow rates may require larger ducts, but the modest efficiency improvements may not be worth the cost of major duct system upgrades. When substantial energy improvements are part of a home retrofit effort, however, the resulting design cooling loads can be significantly lower, and an older, constrictive duct system may be adequate for the target flow rates of a smaller-capacity system. 


\section{Example Effects of Flow Rate}

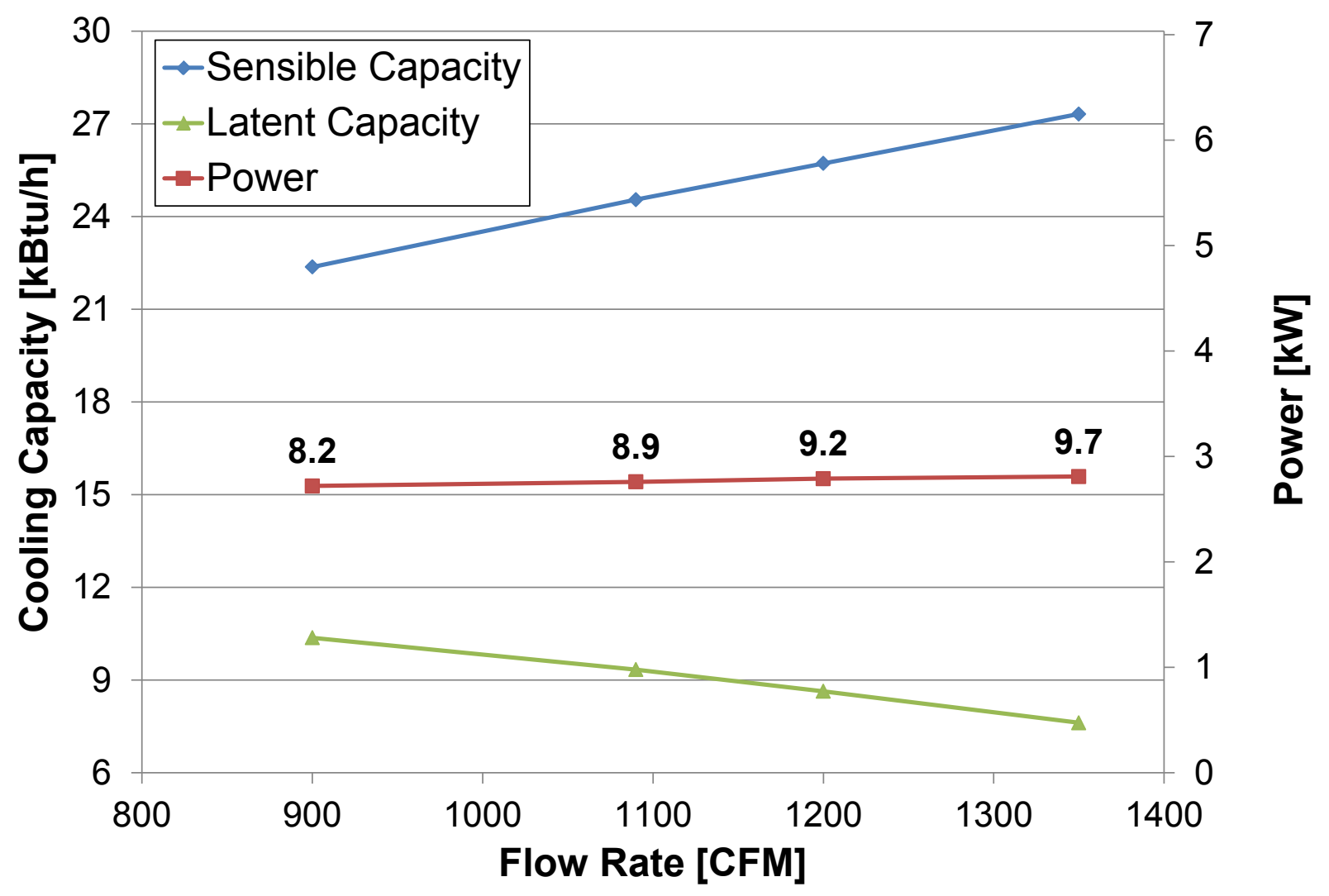

Figure 1. Example effects of flow rate on AC sensible capacity, latent capacity, and power consumption at constant indoor and outdoor conditions and static pressure differential. Numbers above data points refer to sensible EER (Sensible Btu/Wh).

\section{Technical Approach}

To determine the effectiveness of CCCRD's AC standards, short-term performance monitoring of the cooling systems in five unoccupied homes was conducted in late September 2011. Testing was conducted using CARB's portable EER measurement system, which measures system operating conditions and power consumption. These measurements are used to determine the efficiency and capacity of the cooling system. In addition to the EER testing, measurements of system air flows and static pressures were taken. Normal system operating pressure (NSOP) and return static pressure measurements were taken using an Energy Conservatory DG-700 Pressure and Flow Gauge. Total system airflow was measured using an Energy Conservatory TrueFlow flow measurement plate and a DG-700. Air flow rates through individual registers were measured using an Alnor LoFlo Balometer.

\subsection{Portable EER Measurement System}

The portable EER measurement system consists of a Campbell Scientific CR-10X datalogger coupled with a Campbell Scientific AM416 relay multiplexer and other supporting sensors. The datalogger, multiplexer and other support equipment are installed in a Pelican high-impact, hardsided suitcase. 


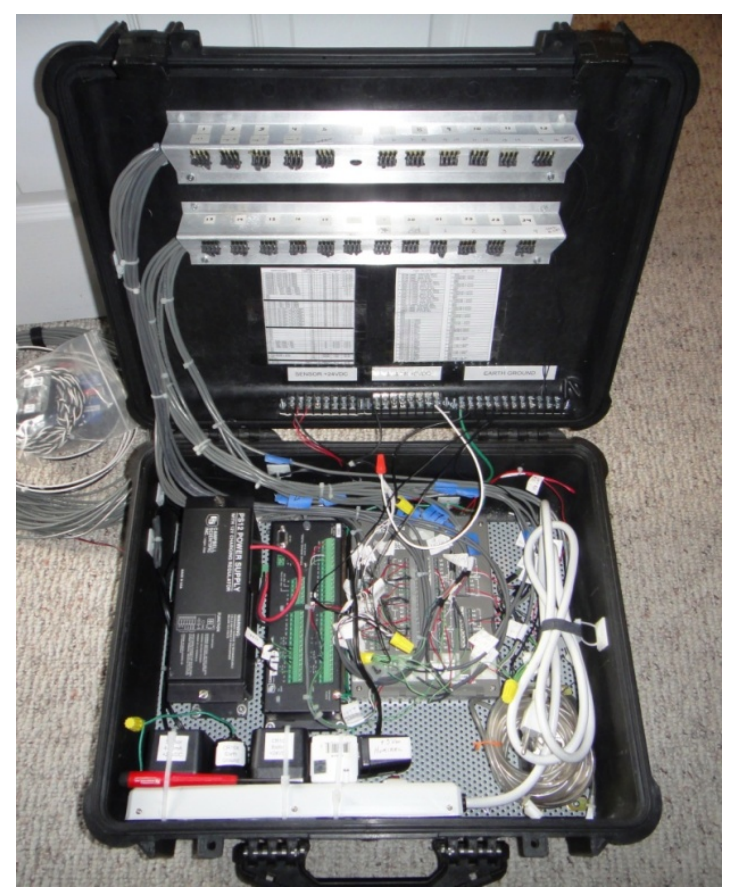

Figure 2. EER portable test system suitcase without sensors

Sensors in the EER measurement system are sampled at 10 -second intervals with data output at 1-minute intervals in the form of averages, minimums, maximums and/or totals over the 1minute time period. Several parameters, listed below, are directly measured at ten-second intervals.

- Ambient (outdoor) air temperature and relative humidity

- Three AHU supply air temperature relative humidity measurements (to be averaged)

- AHU return air temperature and relative humidity

- AHU velocity pressure

- Condensing unit energy consumption (Wh)

- AHU energy consumption (Wh).

Air temperature and relative humidity measurements are made using Humirel HTM2500 temperature and relative humidity probes. For ambient measurements, the probe is located to minimize heat transfer from radiation and surrounding equipment. Electrical energy consumption measurements are made using Continental Control Systems WattNodes coupled with appropriately-sized current transformers (typically 30A at the AHU and 50A at the condensing unit). The WattNode is a true-RMS watt-hour transducer equipped with a pulse-output. The pressure measurement used in calculating airflow is made using a Setra Systems Model 264 differential pressure transducer with a range of 0-1.0 inches of water column and equipped with a 4-20mA output. Velocity pressure at the air handler is measured with an Energy Conservatory TrueFlow flow measurement plate. 
Based on the measured parameters, the following values were calculated. Most calculations are performed using equations from the 2009 ASHRAE Fundamentals Handbook (ASHRAE 2009).

- Saturation vapor pressure

- Water vapor partial pressure

- Supply humidity ratio

- Return humidity ratio

- Supply enthalpy

- Return enthalpy

- Enthalpy differences

- Air density

- Cooling capacities (sensible and latent)

- Sensible heat ratio (SHR)

- $\operatorname{EER}(\mathrm{Btu} / \mathrm{Wh})$.

The saturation pressure over liquid water $p_{w s}$ (psia) is found as a function of dry bulb temperature $T\left({ }^{\circ} \mathrm{R}\right)$

$$
\ln p_{w s}=C_{8} / T+C_{9}+C_{10} T+C_{11} T^{2}+C_{12} T^{3}+C_{13} \ln T
$$

where

\begin{tabular}{|c|c|c|}
\hline$C_{8}$ & $=$ & $-1.0440397 \times 10^{4}$ \\
\hline$C_{9}$ & $=$ & $-1.1294650 \times 10^{1}$ \\
\hline$C_{10}$ & $=$ & $-2.7022355 \times 10^{-2}$, \\
\hline$C_{11}$ & $=$ & $1.2890360 \times 10^{-5}$ \\
\hline$C_{12}$ & $=$ & $-2.4780681 \times 10^{-9}$, and \\
\hline$C_{13}$ & $=$ & $6.5459673 \times 10^{0}$ \\
\hline
\end{tabular}

The partial pressure of water vapor $p_{w}$ (psia) is found as a function of the saturation pressure over liquid water and relative humidity $\phi$ (fraction)

$$
p_{w}=p_{w s} \phi
$$

The humidity ratio $W$ is calculated as a function of the partial pressure of water vapor and atmospheric pressure $p$ (14.696 psia)

$$
W=0.621945 \frac{p_{w}}{p-p_{w}}
$$

The specific enthalpy of dry air $h_{d a}\left(\mathrm{Btu} / \mathrm{lb}_{\mathrm{da}}\right)$ can be approximated as a function of dry bulb temperature $t\left({ }^{\circ} \mathrm{F}\right)$ 


$$
h_{d a}=0.240 t \text {. }
$$

The specific enthalpy of saturated water vapor $h_{g}\left(\mathrm{Btu} / \mathrm{lb}_{\mathrm{w}}\right)$ is similarly approximated as a function of dry bulb temperature

$$
h_{g}=1061+0.44 t .
$$

The specific enthalpy of moist air $h\left(\mathrm{Btu} / \mathrm{lb}_{\mathrm{da}}\right)$ is calculated as a function of the specific enthalpy of dry air, humidity ratio, and the specific enthalpy of water vapor

$$
h=h_{d a}+W h_{g} .
$$

The total cooling capacity $\dot{Q}_{\text {total }}(\mathrm{Btu} / \mathrm{hr})$ is calculated as a function of flow rate $\dot{V}(\mathrm{CFM})$, supply enthalpy $h_{\text {supply }}\left(\mathrm{Btu} / \mathrm{b}_{\mathrm{da}}\right)$, return enthalpy $h_{\text {return }}\left(\mathrm{Btu} / \mathrm{lb}_{\mathrm{da}}\right)$, and the density of dry air $\rho_{d a}$ $\left(0.076474 \mathrm{lb}_{\mathrm{da}} / \mathrm{ft}^{3}\right)$

$$
\dot{Q}_{\text {total }}=\dot{V} \rho_{d a}\left(h_{\text {supply }}-h_{\text {return }}\right) \times 60 \frac{\text { minutes }}{\text { hour }} .
$$

The sensible cooling capacity $\dot{Q}_{\text {sensible }}(\mathrm{Btu} / \mathrm{hr})$ is calculated similarly to the total cooling capacity, but uses the supply and return enthalpies of dry air at the measured dry bulb temperature

$$
\dot{Q}_{\text {sensible }}=\dot{V} \rho_{d a}\left(h_{d a a_{\text {supply }}}-h_{d a, \text { return }}\right) \times 60 \frac{\text { minutes }}{\text { hour }} .
$$

The sensible heat ratio $S H R$ is the dimensionless ratio of the sensible cooling capacity to the total cooling capacity

$$
S H R=\frac{\dot{Q}_{\text {sensible }}}{\dot{Q}_{\text {total }}} .
$$

The energy efficiency ratio $E E R(\mathrm{Btu} / \mathrm{kWh})$ is ratio of total cooling capacity to the electricity consumption of the cooling system $\dot{E}(\mathrm{~kW})$

$$
E E R=\frac{\dot{Q}_{\text {total }}}{\dot{E}} .
$$

\section{CCCRD and CARB Standard Performance Tests}

Each house in this study has a natural gas furnace for heating and an air conditioning system for cooling. Four units have split system air conditioners, and the remaining house has a rooftop packaged unit. With SEER ratings of 15-16, cooling efficiencies for all systems are moderately high. The heating systems installed with the split system air conditioners are condensing natural 
gas furnaces with efficiencies rated at 95\% AFUE, but the packaged rooftop unit is rated at a moderate efficiency of $80 \%$ AFUE. System capacity, type, and efficiency for each house are shown in Table 1.

Table 1. Heating and Cooling System Type, Capacity, and Efficiency

\begin{tabular}{|c|c|c|c|c|c|}
\hline & System Type & SEER & $\begin{array}{c}\text { AC } \\
\text { Capacity } \\
\text { (tons) }\end{array}$ & AFUE & $\begin{array}{c}\text { Heating } \\
\text { Capacity } \\
\text { (kBtu/h) }\end{array}$ \\
\hline House 1 & Split System AC & 16 & 2 & $95.5 \%$ & 69 \\
\hline House 2 & Split System AC & 15 & 2 & $97.5 \%$ & 60 \\
\hline House 3 & Rooftop Package Unit & 15 & 4 & $80.0 \%$ & 115 \\
\hline House 4 & Split System AC & 16 & 3 & $95.5 \%$ & 69 \\
\hline House 5 & Split System AC & 16 & 4 & $95.7 \%$ & 92 \\
\hline
\end{tabular}

The space conditioning equipment model numbers for each house are shown in Table 2.

Table 2. Space Conditioning Equipment Model Numbers

\begin{tabular}{c|c|c|c}
\hline & Indoor Coil & Condensing Unit & AHU/Furnace \\
\hline House 1 & Aspen & Amana & Amana \\
& CE30D44175L004 & ASX160241CA & AMVC950704CXAA \\
House 2 & York & York & York \\
House 3 & N/A & CZE02411A & YP9C060B12MP11A \\
\hline House 4 & Aspen & N/A & Goodman \\
& CQ60A34210T000 & ASXC160361BB & AMVC950704CXAA \\
\hline House 5 & Goodman & Amana & Amana \\
& CHPF486D6DA & ASXC160481AA & AMVC950905DXAB \\
\hline
\end{tabular}

\subsection{Duct System Modifications and Performance}

At the program planning stages, CARB and CCCRD recognized that when substantial energy improvements are part of a home retrofit effort, the resulting design cooling loads can be significantly lower. As a result, an older, constrictive duct system may provide higher flow rates (CFM/ton) when existing condensing units are replaced with smaller units that are sized for the reduced cooling loads. The NSP program provided a unique opportunity to realize increased sensible efficiencies through higher flow rates per ton without replacing the entire duct system.

CCCRD program administrators, auditors, and contractors expected to keep, scrap, or modify the existing duct system, depending on the predicted energy savings and the conditions of the existing system. Auditors evaluated the duct systems based on static pressure measurements, kinks and compression of existing ducts, flows at the registers, and the overall condition of the ducts. Recommendations were made for repair, replacement or addition of ductwork based on the initial audit. The contractors would further assess the adequacy of the existing system by taking into account the size of the new HVAC system to be installed and the practicality of repairing or replacing the systems. 
CARB initially intended to evaluate the duct system screening criteria for replacement or modification, but the practical aspects of the NSP program made this investigation unnecessary. During program implementation, CCCRD auditors, contractors, and program administrators discovered that existing duct systems were commonly not adequately or properly installed. With high static pressures, excessively long runs, and inadequate return ducting, existing duct systems did not meet quality standards. As a result, auditors and contractors recommended new ductwork when practical, and in practice this meant different approaches for one-story and two-story homes. In one-story homes, all ductwork was replaced because the entirety of the system was easily accessible in the attic. Since two-story homes were not gutted, first floor ducting was left in place and only second floor ductwork was replaced.

Duct systems in these five homes were greatly improved during renovation. The associated duct leakages to the outdoors are below $6 \%$ of measured system flow rate in all but one case. System duct leakages and air flow, as measured by CCCRD auditors, are shown in Table 3.

Table 3. Duct System Airflow and Leakage (CCCRD Measurements)

\begin{tabular}{|c|c|c|c|c|}
\hline & $\begin{array}{c}\text { Number of } \\
\text { Floors }\end{array}$ & $\begin{array}{c}\text { Duct Leakage } \\
\text { (CFM@25Pa) }\end{array}$ & $\begin{array}{c}\text { AHU Flow Rate } \\
\text { (CFM) }\end{array}$ & $\begin{array}{c}\text { Duct } \\
\text { Leakage (\%) }\end{array}$ \\
\hline House 1 & 1 & 77 & 1081 & $7.1 \%$ \\
\hline House 2 & 1 & 42 & 1225 & $3.4 \%$ \\
\hline House 3 & 1 & 74 & 1406 & $5.3 \%$ \\
\hline House 4 & 2 & 65 & 1460 & $4.4 \%$ \\
\hline
\end{tabular}

\subsection{System Airflows and Static Pressures}

Two methods were typically used to measure system airflow during field testing. The first method used a flow plate and a digital manometer to measure air flow at the return plenum of the air handling unit. The second method used a balometer to measure flows through the supply registers. The flow plate method is considerably more accurate than the balometer method, which is known to have very high errors on the order of $20 \%$ (Wray et al. 2002).

Clark County auditors measured system airflow using the balometer method. System airflow was measured by CARB using a flow plate, but balometer measurements were also taken to compare individual register airflows to the mechanical design. CCCRD and CARB measured airflows and total external static pressures are compared in Table 4. Calculated total flow measurements using CARB's balometer measurements are listed to provide a more appropriate comparison against CCCRD measurements.

The measurements listed for House 4 were taken at different system stages. CARB measured the system at low stage operation because the system could not be forced into high speed. CCCRD measurements, on the other hand were taken at high stage operation.

CARB measurements for airflow at House 2 are approximate because the configuration of the duct system precluded the use of typical measurement techniques. Several registers were larger than the balometer hood and were measured in parts. Airflow could not be measured at the air handling unit, and instead was measured using two flow plates at the return grilles, which is not as accurate a method. 
Table 4. System Airflows and Static Pressures

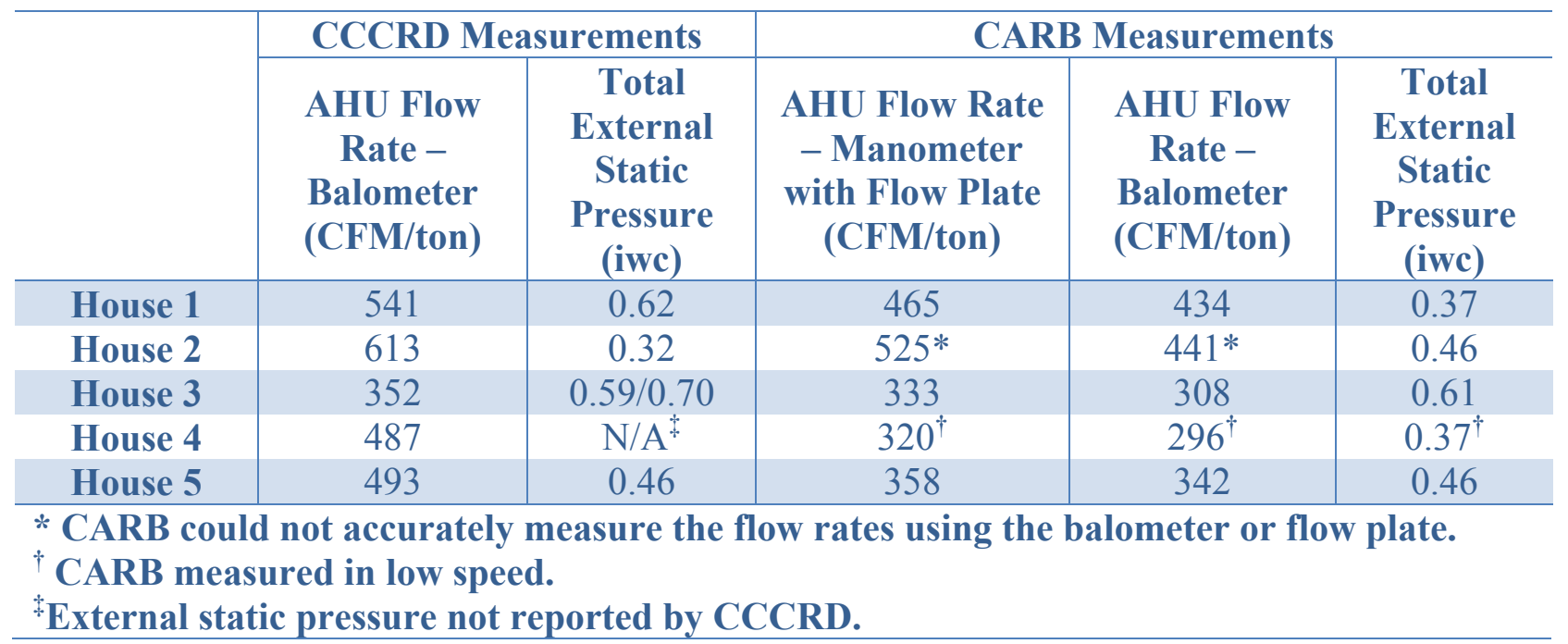

Table 4 shows large discrepancies between the measurements taken by CCCRD and CARB. The airflow measurement discrepancies could be attributed to errors associated with flow hoods (Wray et al. 2002). It is also possible that different brands of flow hoods were used. While total external static pressure measurements can vary somewhat with the exact location of pressure probes, the exact reasons for the disparity between some of CARB's and CCCRD's measurements are presently unknown.

The airflow measurements show that three of the five houses achieved high flow rates per ton and met CCCRD guidelines (400-480 CFM/ton). The packaged rooftop unit (House 3) failed to meet airflow requirements. The duct system was initially sized to provide $392 \mathrm{CFM} /$ ton, and the high measured static pressures suggest that higher flow rates could not be achieved using the installed ductwork. Although House 5 met CCCRD requirements according to the auditor measurements, CARB's measurements show the system failing to meet those requirements.

\section{Portable EER Measurement System Results}

Although the portable EER system is meant to measure sensible cooling capacity, total cooling capacity, and mechanical system power consumption, issues with some of the sensors calls into question the accuracy of the power consumption and total cooling capacity measurements. Electric consumption measurement inaccuracy stemmed from a severe inaccuracy in the Continental Control Systems CTS Series split core current transformers used in the portable EER measurement system. Total system cooling capacity inaccuracy stemmed from a faulty return RH sensor and error propagation from the Humirel HTM2500 temperature and relative humidity probes.

During a field EER test, CARB noticed discrepancies in power consumption measurements, and contacted Continental Control Systems to resolve the problem. As explained by the application engineer, these current transformers experience rather alarming phase angle inaccuracies when used to monitor currents below 70A, information that was not previously published. Since the current transformers used in this application were rated at 30 and 50 amps, significantly below 
the 70A phase angle error threshold, monitored power consumption is inaccurate. The inaccuracies are even more severe when the monitored load has a low power factor. The CTS Series datasheet now states that the phase angle is rated to be $<2^{\circ}$ at $50 \%$ of rated current, but this rating is valid only for $70 \mathrm{~A}$ or higher. Below 70A, the error is unknown and could be considerably worse, particularly if the load being monitored also has a low power factor (Continental Control Systems 2011).

When analyzing the EER system data, the measured total cooling capacities were considerably larger than the rated capacities under the measured conditions. After extensive analysis, CARB determined that this discrepancy was caused by an unfortunate combination of a faulty return duct RH sensor and surprising error propagation in dry climates. CARB tested all humidity sensors in the lab under standard room conditions and observed a $4.2 \%$ humidity difference between the return RH sensor and the three supply RH sensors, which were within $1.5 \% \mathrm{RH}$ of each other.

The measured $4.2 \%$ humidity difference between the sensors was amplified through error propagation in the cooling capacity calculations. Extensive analysis of the effect of the humidity sensor error at various conditions showed that the operating conditions of the monitored Las Vegas air conditioning systems provided a worst case scenario for error propagation. The latent capacity calculations are dependent on the humidity ratio, which is more sensitive to relative humidity at higher dry bulb temperatures. As a result, a combination of a large temperature difference across the coil and high return temperatures will produce the largest propagation of error from the relative humidity measurements to the latent capacity. In these homes, thermostats in these unoccupied residences were set to around $80^{\circ} \mathrm{F}$ before the testing commenced, and the operating conditions created a typical temperature difference of $20^{\circ} \mathrm{F}$ across the coil, which is at the high end of the manufacturer specifications. CARB is currently investigating more robust sensors for use in calculating latent cooling capacity.

Despite the issues with the relative humidity sensors and current transformers, the portable EER measurement system provided valuable information about the performance of the cooling systems through measurement of the sensible cooling capacities. These measured capacities can be compared to manufacturer-listed capacities to ensure that these systems are performing as expected.

System cooling performance is typically listed by the manufacturer in tabular form as a function of indoor dry bulb temperature, indoor wet bulb temperature, outdoor dry bulb temperature, and airflow. Listed values include total system capacity, sensible system capacity, and power consumption. These values are listed for a specific combination of air handling unit, outdoor unit, and indoor coil. If a specific combination was not listed, or if all of the equipment was not manufactured by the same company, CARB selected a comparable combination based on professional judgment.

Since the listed power consumption and capacities are given in tabular form with relatively large differences between the listed values of the dependent variables, an interpolation method was used to match the listed values to the measured system variables. A quadratic interpolation method using the equation below was used to predict the performance of the system under the measured conditions 


$$
p=b+\sum_{i=0}^{2} \sum_{j=0}^{2} \sum_{k=0}^{2} \sum_{l=0}^{2} a_{i j k l} t_{i n, d b}{ }^{i} t_{i n, w b}{ }^{j} t_{o u t, d b}{ }^{k} \dot{V}^{l}
$$

where

$$
\begin{array}{lll}
a_{i j k l} & = & \text { interpolation coefficients, } \\
b & = & \text { constant interpolation coefficient, } \\
p & = & \text { predicted value of power, total capacity, or sensible capacity, } \\
t_{i n, d b} & = & \text { indoor dry bulb temperature }\left({ }^{\circ} \mathrm{F}\right), \\
t_{i n, w b} & = & \text { indoor wet bulb temperature }\left({ }^{\circ} \mathrm{F}\right), \\
t_{\text {out }, d b} & = & \text { outdoor dry bulb temperature }\left({ }^{\circ} \mathrm{F}\right), \text { and } \\
\dot{V} & = & \text { flow rate }(\mathrm{CFM}) .
\end{array}
$$

Interpolations with independent coefficients, $a_{i j k l}$ and $b$, were generated for power, total capacity, and sensible capacity for each cooling system monitored. Each interpolation has its own set of interpolation coefficients. All interpolations had $\mathrm{R}^{2}$ values greater than 0.96 .

Figure 3 shows measured system sensible cooling capacities against the interpolations of manufacturer's listed capacities at the measured system operating conditions. The interpolated manufacturer data is shown as a function of system airflow to display the impact of airflow rates on system capacity. In four of the five cases, the measured system capacity was close to the manufacturer rated values. This shows that by increasing the flow rate across the coils, CCCRD was able to increase system capacity. System capacity at House 3 was considerably lower than the manufacturer's listed specifications, which indicates a potential issue with the operation of the unit.

Although the total system efficiency of the units could not be measured, Figure 4 shows the predicted impact on the sensible efficiency of the unit based on the manufacturer's rated specifications. Efficiency is listed as sensible EER. The packaged rooftop unit was excluded from these graphs because the system does not operate near the manufacturer's rating.

These graphs show that sensible EER improvements vary significantly between systems. For example, the House 2 system has a slight slope of improvement, while the House 1 system has a steeper slope of improvement. The sensible EER improvement correlates strongly with the degree of oversizing of the indoor coil against the outdoor unit. A qualitative analysis is shown in Table 5, where coil sizes are compared to a qualitative observation of the slope of the sensible EER improvement shown in Figure 4.

Table 5. Coil Sizing and Impact on Slope of Sensible EER Improvement

\begin{tabular}{|c|c|c|c|}
\hline & $\begin{array}{c}\text { Indoor Coil } \\
\text { Tonnage }\end{array}$ & $\begin{array}{c}\text { Condensing } \\
\text { Unit Tonnage }\end{array}$ & $\begin{array}{c}\text { Slope of } \\
\text { Sensible EER } \\
\text { Improvement }\end{array}$ \\
\hline House 1 & 3 & 2 & Steep \\
\hline House 2 & 2 & 2 & Slight \\
House 4 & 5 & 3 & Steep \\
House 5 & $4-5$ & 4 & Moderate \\
\hline
\end{tabular}




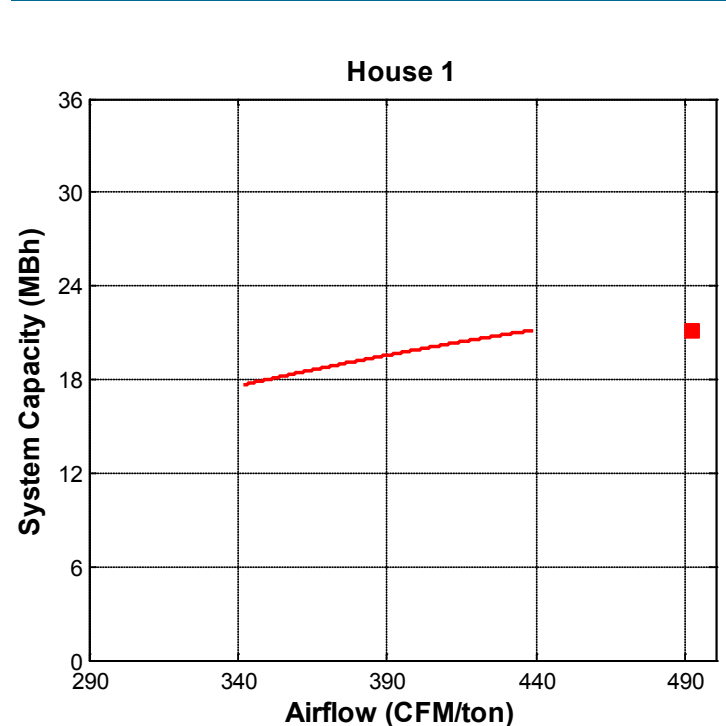

House 2

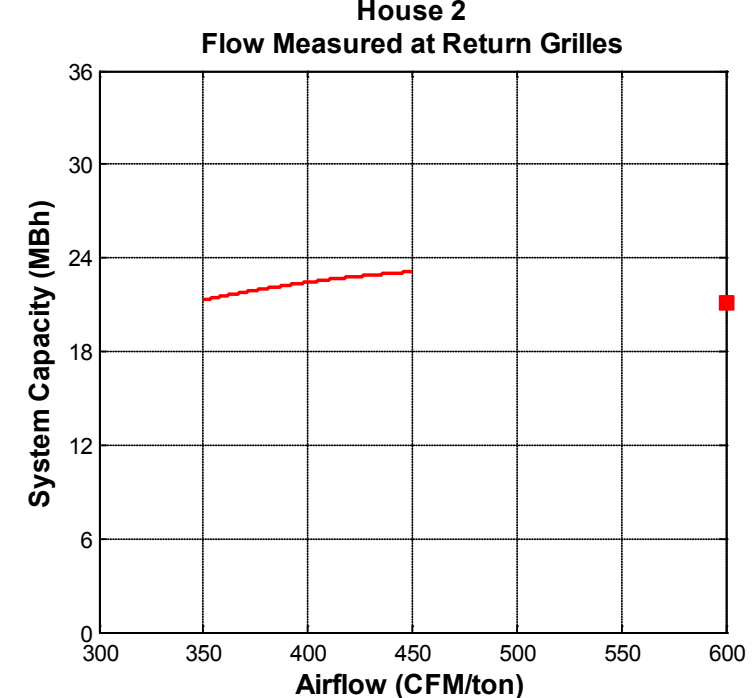

House 4
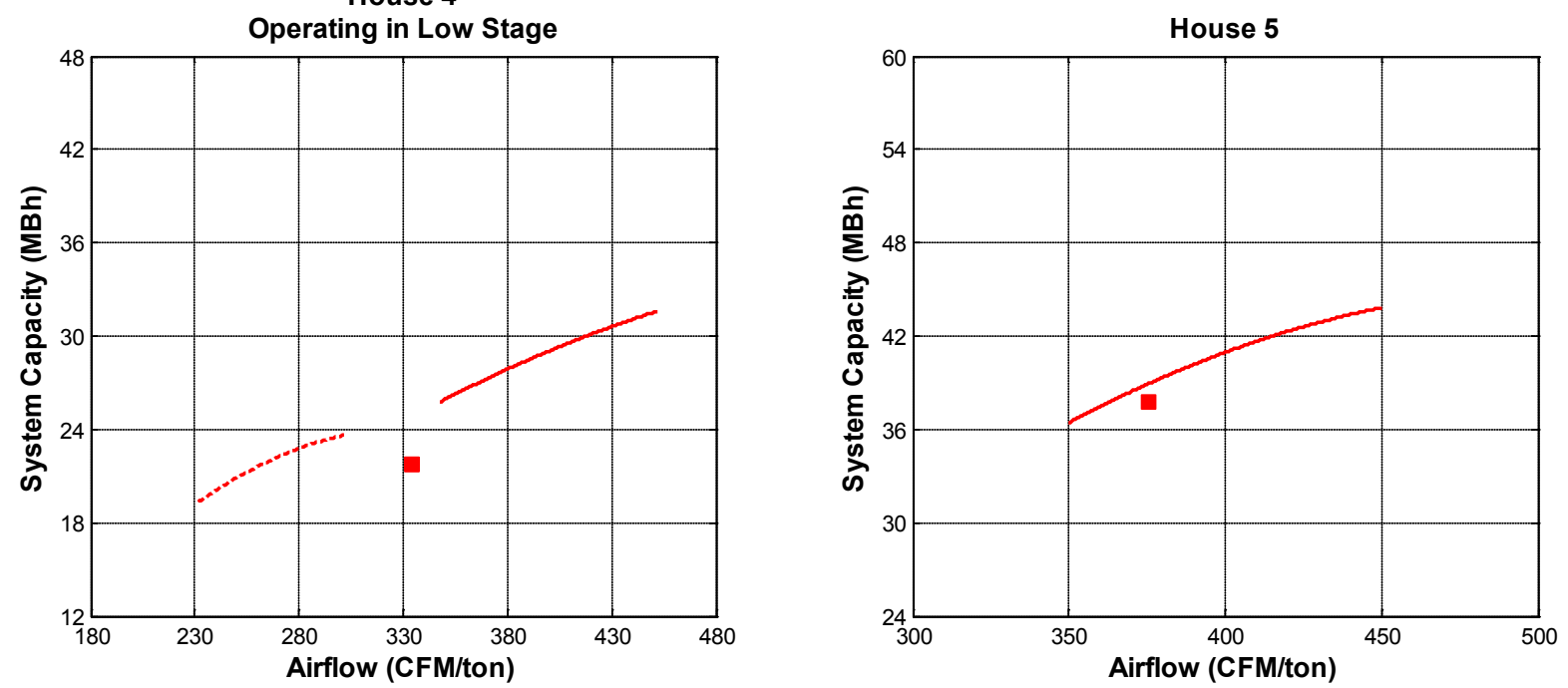

House 3

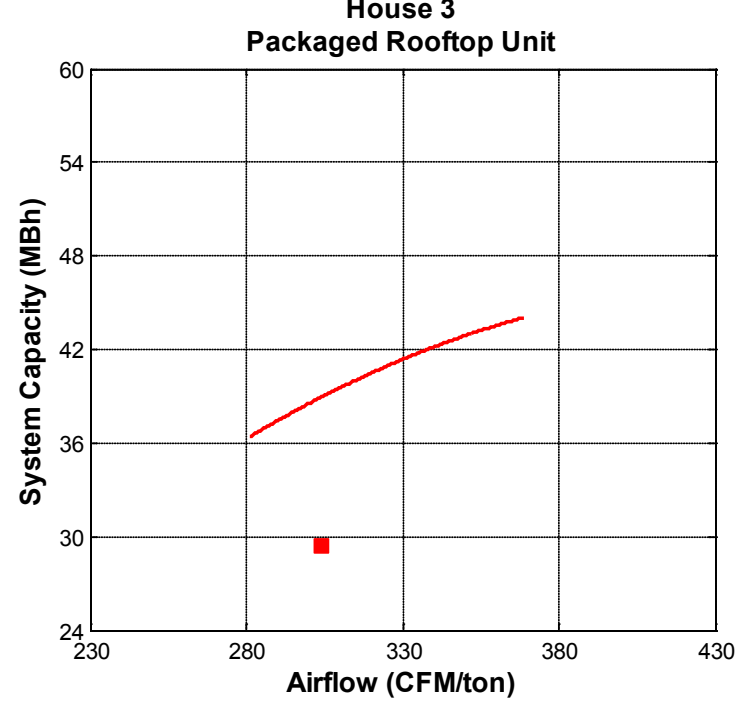

Airflow (CFM/ton)

Figure 3. Manufacturer-listed and measured sensible capacity. CCCRD measured flow rate used for House 2. 

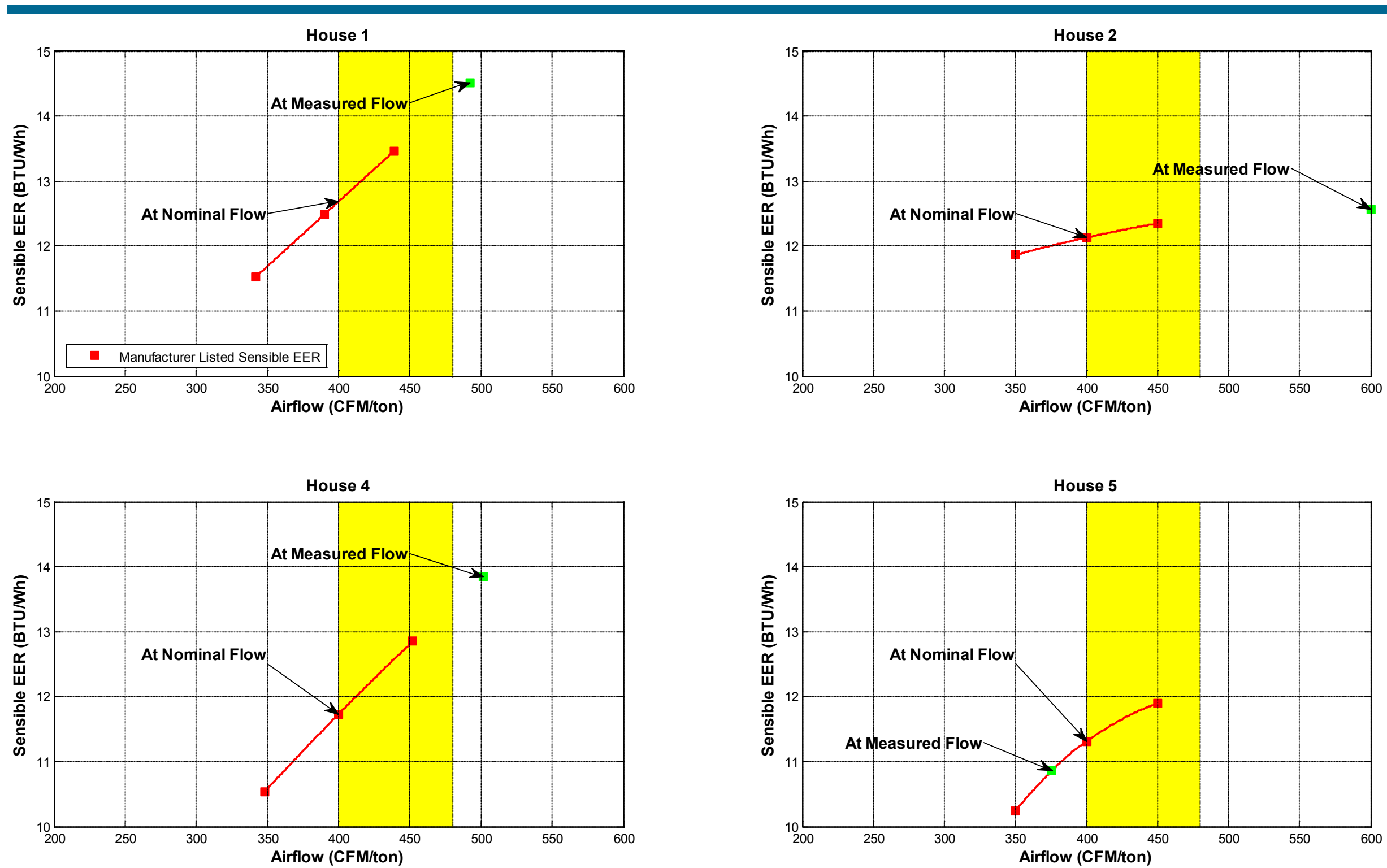

Figure 4. Manufacturer-listed sensible EER 


\section{Predicted Cost Savings}

The cost savings of this measure were calculated by comparing the energy savings associated with increasing the airflow of the system from $360 \mathrm{CFM} /$ ton to $450 \mathrm{CFM} /$ ton for a $1,700-\mathrm{ft}^{2}$ representative home in the Clark County NSP project. The representative home was modeled in BEopt, and the energy efficiency improvement associated with the increased airflow was assumed to be a $9 \%$ increase in the EER rating of the air conditioning unit. If this home were able to achieve higher flow rates ( $450 \mathrm{CFM} /$ ton), the annual cooling costs would be reduced by $\$ 33.27$ per year (assuming \$0.114 per $\mathrm{kWh}$ ).

Achieving higher flow rates in cooling systems is probably only practical and cost effective when the duct system is in need of major repairs or replacement, or the home energy improvements reduce the design load such that the existing ducts can carry a higher flow rate (per ton) with the new, smaller cooling equipment. In the case of CCCRD, the auditors determined that the duct systems needed to be replaced for reasons independent of the system flow rate. As a result, the costs associated with this measure are labor and material costs of installing a larger indoor coil and larger ductwork. CARB assumed that the increased airflows would require contractors to install coils and ductwork one size larger than the typical sizes for the unit capacity. For this home, the increased duct sizes are assumed to cost $\$ 0.30$ per linear foot and the larger coil costs $\$ 100$. The costs assumptions are shown in Table 6.

Table 6. Cost of Increased Sensible Cooling Efficiency Measures

\begin{tabular}{c|c}
\hline Larger Indoor Coil & $\$ 100$ \\
Larger Duct Sizes & $\$ 100$ \\
\hline Labor and Miscellaneous Charges & $\$ 0-\$ 200$ \\
\hline Total & $\$ 200-\$ 400$ \\
\hline
\end{tabular}

The cost analysis was performed as described by Polly et al. (2011). The assumptions and results are listed in Table 7 , and the annualized rate of return was found to be $6 \%$ to $32 \%$. The costs were assumed to be wrapped into a 5 -year loan at a $7 \%$ interest rate.

Table 7. Cost Analysis Assumptions and Results

\begin{tabular}{|c|c|}
\hline Analysis Period & 30 years \\
\hline Inflation Rate & $3 \%$ \\
Loan Rate & $7 \%$ \\
\hline Loan Period & 5 years \\
Measure Cost & $\$ 200-\$ 400$ \\
Measure Lifetime & 20 years \\
\hline Annualized Rate of Return & $6 \%-32 \%$ \\
\hline
\end{tabular}

These savings may be modest when compared to home envelope energy improvements, but they may be comparable to strategies such as duct sealing. According to the National Residential Efficiency Measures Database (NREL 2011), the cost of duct sealing in this example home to reduce leakage from $30 \%$ to $15 \%$ might range from $\$ 250$ - $\$ 1,250$, resulting in an annual cooling savings of $\$ 20-\$ 50$. 


\section{Conclusion}

In hot, dry climates, sensible cooling efficiencies can be improved by increasing the flow rate across the air handling unit and increasing the size of the indoor coil. Design manuals indicate that increasing airflow and indoor coil size will increase sensible capacity and decrease latent capacity (ACCA 1995, Rudd 2006). In hot, dry climates where large latent cooling loads generally do not exist, trading latent capacity for sensible capacity is often desirable.

Furthermore, the increased sensible cooling capacity is associated with a much smaller increase in power consumption, which is mostly caused by increased fan energy usage. As a result, effective sensible EER ratings are increased. Manual S (Rutkowski 1995) considers mismatched coils acceptable as long as performance criteria are met. Although larger indoor coils are preferable for hot, dry climates, furnace-condenser-indoor coil matches should have available performance ratings to avoid potential performance issues and conform to energy program documentation requirements.

Although higher flow rates may not be possible with existing duct systems, CCCRD and CARB recognized that when substantial energy improvements result in a significant reduction in design cooling loads, an older and constrictive duct system may adequately provide higher flow rates (CFM/ton) when a smaller condensing unit is installed. The CCCRD NSP program provided an opportunity to test the feasibility of using older ductwork to provide higher flow rates per ton as part of a comprehensive energy efficiency upgrade. In practice, however, CCCRD auditors and contractors determined that most existing duct systems needed to be replaced for reasons such as improper design, damage, or poor workmanship.

Detailed monitoring of five air conditioning systems in CCCRD-retrofitted homes provided valuable information about the success of CCCRD in achieving air flow targets set from their guidelines and the potential to increase the sensible efficiencies of their mechanical systems. CARB determined that three of the five homes met or exceeded CCCRD targets for flow rate. Of the two homes that failed the requirements, one contained ductwork that was never designed for flow rates greater than $400 \mathrm{CFM} /$ ton. The second home met the requirements under the auditor ratings, but failed to meet the flow rate requirements under CARB testing.

Although issues with the portable EER measurement system precluded direct measurement of efficiency, measured sensible capacities showed that in most cases the sensible capacity of the system met manufacturer's ratings. The only case that did not meet the manufacturer's ratings was a packaged rooftop unit. A qualitative analysis of the manufacturer ratings showed that when indoor coils are oversized, the improvement in the sensible efficiency is greater as airflows improve.

Since duct systems were typically replaced during renovation for reasons beyond total system flow rate, the overall cost associated with increasing flow rates across the air handling unit were minimal. The resulting utility bill savings of this measure, although small, are cost effective. The annualized rate of return of this measure was $6 \%$ to $32 \%$. 


\title{
Appendix: Program Evaluation Report for CCCRD
}

Steven Winter Associates, Inc. $\quad 50$ Washington Street

Building System Consultants

\author{
Norwalk, CT 06854
}

Telephone: (203) 857-0200

Telefax: (203) 852-0741

Web: mun.swinter.com

Program Evaluation of

Phase I of the Department of Housing and Urban Development's

Neighborhood Stabilization Program

In Clark County, Nevada

\author{
Prepared by: \\ Lois B. Arena \\ Steven Winter Associates, Inc. \\ of the \\ Consortium for Advanced Residential Buildings (CARB) \\ 50 Washington Street \\ Norwalk, CT 06854
}

August 2011 
Steven Winter Associates, Inc. Building System Consultants
50 Washington Street Norwalk, CT 06854
Telephone: (203) 857-0200

Telefax: (203) 852-074

Web: $\quad$ mww.swinter.com

\section{Introduction}

The Neighborhood Stabilization Program is administered by the Department of Housing and Urban Development (HUD) and was established for the purpose of stabilizing communities that have suffered from foreclosures and abandonment. Specific goals of this program include stabilizing the housing market, providing durable, low cost homes, providing down payment assistance and creating jobs in the construction industry. Because foreclosure and abandonment rates in Nevada were among the worst in the nation, Clark County received just over 25 million dollars in state and federal funding under the NSP.

Between 2010 and 2011, 184 homes were retrofitted under the NSP in Clark County (CC), NV. Year of construction of these homes ranged from 1979 to 2007. Improvements performed included energy efficiency upgrades, health and safety repairs, cosmetic repairs and improvements to bring homes into compliance with local codes.

To evaluate the performance of $\mathrm{CC}^{\prime}$ 's program and provide program administrators with information to help them improve the structure of their program under the next phase of their NSP, Steven Winter Associates, Inc., (SWA), collected and analyzed data for 40 homes, approximately $22 \%$ of the program total. Steven Winter Associates, Inc. is the lead for the Department of Energy's Building America team called the Consortium for Advanced Residential Buildings (CARB).

Data collected for this analysis included test in (before improvements), predicted (recommended by auditors) and test out (after improvements) values for:

- Efficiency levels of all building components including walls, ceilings, foundations and windows;

- Mechanical system efficiencies;

- Air leakage values;

- Duct leakage values.

In addition to the above, cost information was collected for all energy efficiency improvements as well as health and safety upgrades and cosmetic repairs. Predicted costs and actual costs were recorded for all categories. Data was analyzed with and without regard to year of construction. The following report explains the results of that analysis. 
Predicted vs. Actual Efficiency Improvements

First, overall program evaluation was conducted by analyzing the data without regard to year of construction. Table 1 displays the average efficiency values for the building components, mechanical systems, and air and duct leakage values for all 40 homes.

Table 1. Predicted vs. Actual Average Efficiency Values for 40 Retrofitted Homes in Clark County, NV under HUD's NSP

\section{LAS VEGAS RETROFITS PROJECT \\ ENERGY EFFCIENCY AND COST SUMMARY}

\begin{tabular}{|c|c|c|c|}
\hline \multicolumn{4}{|l|}{ DATABASE INFORMATION } \\
\hline \multicolumn{3}{|l|}{ No. of Houses in Database } & 40 \\
\hline \multicolumn{3}{|l|}{ No. of Houses Selected for this Report } & 40 \\
\hline \multicolumn{3}{|l|}{ Time Period } & 1979-2007 \\
\hline \multirow[b]{2}{*}{ Category } & \multicolumn{3}{|c|}{ Phase } \\
\hline & $\begin{array}{l}\text { Test In } \\
\text { Average }\end{array}$ & Predicted Average & Test Out Average \\
\hline
\end{tabular}

HOUSE CHARACTERISTICS SUMMARY

\begin{tabular}{|l|c|c|c|}
\hline Envelope & 23.1 & 41.1 & 42.4 \\
\hline Attic R value & 0.0 & 4.2 & 3.9 \\
\hline Slab R value & 13.0 & 21.5 & 18.5 \\
\hline Floor R value & 0.82 & 0.51 & 0.49 \\
\hline Window U value & 0.69 & 0.40 & 0.37 \\
\hline Window SHGC & 1630 & 887 & 941 \\
\hline Air Leakage (CFM@50) & $10.4 \%$ & $5.6 \%$ & $5.1 \%$ \\
\hline Duct Leakage & 79.2 & 86 & 87.3 \\
\hline Heat AFUE & 6.8 & 8.3 & 8.25 \\
\hline Heat HSPF & 10.3 & 15 & 15.1 \\
\hline Cool SEER & 0.58 & 0.64 & 0.65 \\
\hline DHW EF & 121 & 74 & 69 \\
\hline HERS Index & $\$ 2,222$ & $\$ 1,494$ & $\$ 1,416$ \\
\hline Predicted Utility Bills & & & \\
\hline \$0.1143/kWh for electricity & & & \\
\hline \$1.0987/therm for natural gas & & & \\
\hline
\end{tabular}

In most cases, the final or Test Out average energy efficiency of each component met or exceeded the value recommended by the auditors. The only category where improvements did not meet or exceed the predicted levels was Air Leakage, but the difference between the predicted and test out values was not significant. On average, auditors recommended a $46 \%$ reduction in air leakage, and the test out numbers reveal an average reduction of $42 \%$.

Based on the Test In and Test Out results, the average utility bill savings for this sample is anticipated to be approximately $\$ 806$ peryear. The average HERS Index is 69 . 
Estimated vs. Actual Costs

Costs were evaluated several ways. First, the average cost per upgrade for each energy efficiency upgrade was calculated. These values are listed in Table 2 . Only homes which actually received an upgrade to the component listed were included in the average. For example, if only 13 homes in the 40 home sample received attic insulation, the total cost of attic insulation improvements was divided by 13 , not 40 . This provides a more accurate estimate of the average cost per upgrade.

Table 2. Predicted vs. Actual Improvement Costs for 40 Retrofitted Homes in Clark County, NV under HUD's NSP

\begin{tabular}{l|c|c|c|}
\hline COST SUMMARY - Average Costs per Upgrade* & & & \\
\hline Envelope & & Actual & Sample Size \\
\hline Attic Insulation & $\$ 1,667$ & $\$ 1,887$ & 34 \\
\hline Foundation Insulation & $\$ 1,739$ & $\$ 1,048$ & 16 \\
\hline Windows & $\$ 4,036$ & $\$ 3,835$ & 36 \\
\hline Exterior Doors & $\$ 456$ & $\$ 723$ & 24 \\
\hline Air Sealing & $\$ 872$ & $\$ 1,244$ & 37 \\
\hline Mechanical & & & \\
\hline HNAC Replacement & $\$ 8,333$ & $\$ 9,436$ & 39 \\
\hline Duct Repair/nsulation & $\$ 607$ & $\$ 915$ & 12 \\
\hline DHW Replacement & $\$ 1,178$ & $\$ 2,368$ & 25 \\
\hline DHW Insulation & $\$ 40$ & $\$ 66$ & 29 \\
\hline Mechanical Ventilation & $\$ 876$ & $\$ 1,252$ & 25 \\
\hline Lighting \& Appliances & & & \\
\hline Lighting & $\$ 413$ & $\$ 614$ & 36 \\
\hline Appliances & $\$ 2,430$ & $\$ 2,946$ & 38 \\
\hline $\begin{array}{l}\text { Miscellaneous Energy Efficiency } \\
\text { Low Flow Fixtures }\end{array}$ & $\$ 791$ & $\$ 529$ & 10 \\
\hline
\end{tabular}

${ }^{*}$ Costs averaged over number of actual jobs, not total number of homes in sample.

The estimated costs were compared to the actual costs. The most significant differences appear to be in the mechanical systems category. On average, the actual costs for mechanical system improvements HVAC, DHW and Mechanical Ventilation combined - were $27 \%$ higher than the initial bids.

There could be many reasons for this increase, but one of the most common was underbidding. The mechanical contractors were not familiar with the amount of testing associated with installing HVAC systems to the standards required by Clark County. Performing design calculations and commissioning the systems once installed are tasks most HVAC contractors in that area were unfamiliar with. Not understanding the requirements, they underbid the work and then regularly increased their prices once work began. It should be noted, that most of the requirements come from the ACCA's standards for quality installation of air conditioning equipment. These are standards that all mechanical contractors should be familiar with, but unfortunately that is very commonly not the case. This is a problem nationwide, not just in Clark County.

Cost information is displayed again in Table 3, but this time the costs are separated into the three major categories of improvements and are averaged over all 40 homes. This shows the average costs for energy efficiency upgrades, health and safety improvements and code and cosmetic repairs across the 
Steven Winter Associates, Inc.

whole sample. These categories and the improvements included in each are based on the standard bid form required by $C C$.

Table 3. Predicted vs. Actual Improvement Costs for 40 Retrofitted Homes in Clark County, NV under HUD's NSP

\begin{tabular}{|l|c|c|}
\hline Summary** & Estimate & Actual \\
\hline Energy Efficiency & $\$ 21,601$ & $\$ 23,869$ \\
\hline Health \& Safety & $\$ 2,557$ & $\$ 3,178$ \\
\hline Code/Cosmetic & $\$ 19,017$ & $\$ 27,495$ \\
\hline Grand Total & $\$ 43,175$ & $\$ 54,542$ \\
\hline & & \\
\hline **Total of all costs per category divided by total number of homes in study (40). & \\
\hline
\end{tabular}

While each category shows an increase between the actual and estimated costs, the biggest jump is associated with code and cosmetic improvements which shows a $45 \%$ increase over what was originally estimated. It is unclear at this time why there is such a difference. CARB will review this issue with program administrators to determine the major factors associated with this price jump.

\section{Evaluation by Year of Construction}

In addition to the above analysis, CARB analyzed the program performance based on the year of construction of the homes. The oldest home in the sample set was constructed in 1979 and the newest in 2007. Of the 40 homes in this sample, 8 homes in the sample were built in the 1980 's, 13 in the 90 's, and 19 between 2000 and 2007.

A breakdown of the predicted reduction in energy use, improvement cost per home, and the cost per $\mathrm{ft}^{2}$ per MMBtu reduction is displayed in Table 4 for each of the 3 major time periods.

Table 4. Evaluation of Sample Homes by Year of Construction

Sample Statistics by Year of Construction

\begin{tabular}{l|c|c|c}
$\quad$ Category & $1980-89$ & $1990-99$ & $2000-2007$ \\
\hline Percent Reduction in Energy Use & $36 \%$ & $35 \%$ & $24 \%$ \\
\hline Average Cost per home & $\$ 66,710$ & $\$ 61,780$ & $\$ 44,467$ \\
\hline Average Cost/f2/MMBtu & $\$ 1.13$ & $\$ 1.14$ & $\$ 0.99$ \\
\hline Number of Homes in Next Round ${ }^{1}$ & 45 & 49 & 67 \\
\hline Predicted MMBtu's Saved in Next Round $^{2}$ & 1,749 & 1,782 & 1,747
\end{tabular}

${ }^{1}$ Based on $\$ 3$ million in NSPS funding for improvements and the Average Cost per home displaved above.

${ }^{2}$ Number of Homes in Next Round multiplied by average annual energy savings per age group as predicted using REM/Rate.

As can be seen in the above table, the percent reduction in energy use decreases for the newer homes in the sample, indicating that the newer homes were more efficient. According to program administrators in CC, around the year 2000, the Energy Star (ES) Homes program was initiated in this area, and since then, $80 \%$ of all new housing in Clark County has been built to those standards. For this sample set, the average HERS index for homes built in the 80 's was approximately 135 , while the average index for the homes built in the 2000's was 111 (a lower HERS index is better). Since the newer 
Steven Winter Associates, Inc. Building System Consultants
50 Washington Street Norwalk, CT 06854
Telephone: (203) 857-0200

Telefax: (203) 852-0741

Web: $\quad$ www.swinter.com

homes start off more efficient, the reduction in energy use will be smaller than those homes that are less efficient.

Additionally, as displayed in Figure 1 below, the average cost per $\mathrm{ft}^{2}$ per MMBtu per year for energy improvements actually increases for the newer homes. Essentially, this means that the costs to reduce energy are higher in a more efficient home than they are in an older, less efficient home. This is the law of diminishing returns. But, energy improvements are not the only costs when retrofitting a home. Health and safety issues such as mold, asbestos and lead must be addressed before any other work can be performed. Compliance with current building codes was also mandated in this program. Finally, there are usually cosmetic repairs that must be addressed before the home can be resold. If all these costs are taken into account, the cost per $\mathrm{ft}^{2}$ per MMBtu reduction was actually lower in the new homes, even though they saw the lowest reduction in energy use. This is because all the other costs listed above were much lower for the new homes (see Figure 1). This resulted in a total cost that was lower than the older homes.

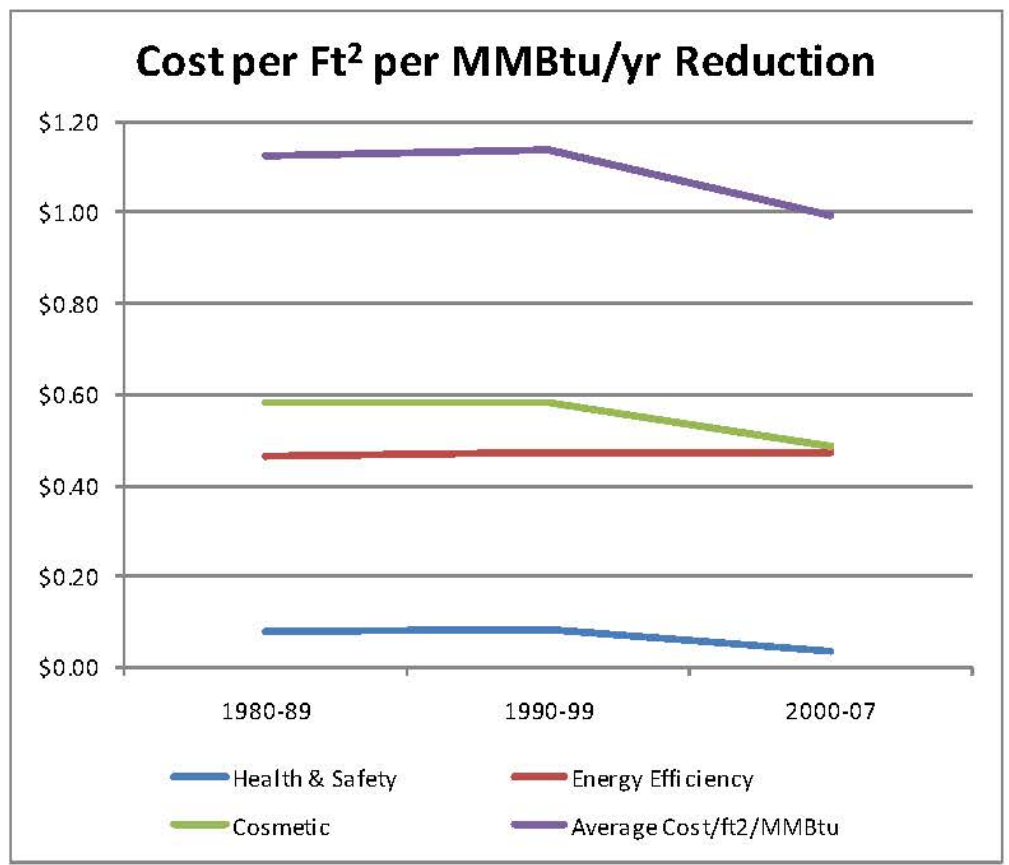

Figure 1. Cost per $\mathrm{ft}^{2}$ per MMBtu/yr reduction in energy use by year of construction. 
Steven Winter Associates, Inc. Building System Consultants
50 Washington Street Norwalk, CT 06854
Telephone: (203) 857-0200

Telefax: (203) 852-0741

Web: www.swinter.com

\section{Recommendations}

Because the housing stock for the next phase will primarily have been constructed in the 1980's and earlier, a particular focus was placed on the analysis for the older houses retrofitted in the first phase. There are a few recommendations that are evident based on the data analysis so far.

1. Review the costs per upgrade. Some seem uncharacteristically high such as the DHW replacements and the Mechanical Ventilation. The DHW upgrades are the least cost-effective of all that have been performed (on average). Have other costs been buried in these upgrades? What can be done to bring these costs down. Are they necessary?

2. Based on energy modeling with REM/Rate and the data provided the most cost-effective upgrades of those performed through this program and for this climate and housing stock appear to be: a) air sealing, b) HVAC upgrades to mechanical equipment and ductwork, and c) window improvements, especially when lowering the SHGC.

Further investigation with program managers and aud itors into the costs and work performed is necessary to make more specific recommendations. Information such as combined costs in various improvement categories and barriers to proper implementation should be discussed.

\section{Conclusions}

In the next phase of this program, $\mathrm{CC}$ is aiming for a maximum budget per house of $\$ 50 \mathrm{k}$ based on the funds allocated and the cost assumptions for acquisition to meet the required number of units assisted in a certain area as determined by HUD's protocol. For the target neighborhood, it was determined that a minimum of 60 single family homes should be impacted by the NSP3 funds. Therefore, of the $\$ 9.25$ million allocated to acquisition/rehab in CC, \$3 million has been slated for actual rehabilitation.

The target area designated for assistance consists of neighborhoods where the homes are significantly older, on average, than those in the last phase. This will likely result in more remediation with respect to lead, asbestos and mold, higher costs to bring the homes to compliance and, most likely, higher costs for cosmetic repairs. Considering that in the last phase, the average retrofit cost for homes built prior to 2000 was higher than the intended $\$ 50 \mathrm{k}$ cap for NSP3, the budget left for energy improvements will likely be considerably smaller.

The last two rows of Table 4 above show the impact that these other non-energy efficiency improvements have on overall NSP program goals and success. These rows show that if new homes are the focus (and the same level of funding is spent per home as the previous round), more homes can be retrofitted which will provide more jobs to the construction industry and more homes to the target market. Based on the average costs to retrofit a home in each of these time brackets from the last round of funding, 67 homes could be retrofitted if built since 2000 while only 45 homes could be retrofitted if built in the 80 's.

The last row of that table shows the total predicted energy savings for the program in the next round if the number of homes indicated can be retrofitted. The conclusion is that the same amount of energy would be saved whether the program retrofits 1980 's homes vs. 2000 's homes because of the larger number of homes that can be addressed. Program wide energy reductions would be about the same, 
Steven Winter Associates, Inc. Building System Consultants
50 Washington Street Norwalk, CT 06854
Telephone: (203) 857-0200

Telefax: (203) 852-0741

Web: $\quad$ www.swinter.com

but more jobs would be created and more homes provided to $\mathrm{CC}$ residents. Given the age of the homes chosen for the next round ( 1960 to 1970 ), it is possible that the energy savings could actually be less since the amount of budget left for energy improvements is likely to be smaller.

But program admin istrators feel that, in many ways, the older homes are an even greater priority due to the environmental hazards and the amount of work needed in order for the property to be healthy and safe for its occupants. They reason that older neighborhoods are likely less attractive to investors and rehab is probably not an option for most of the low-moderate income owners of those properties due to lack of funds. Although one strategy might be to pick the neighborhoods with the newest homes to possibly assist a greater number and to maximize program wide energy savings, NSP has a lot of other factors and requirements to consider related to neighborhood stabilization and property eligibility. 


\section{References}

ACCA (2007). ACCA Standard 5: HVAC Quality Installation Specification. Arlington, VA: Air Conditioning Contractors of America. https://www.acca.org/Files/?id=116. Accessed July 28, 2011.

ACCA (2008). Technician's Guide for Quality Installations. Arlington, VA: Air Conditioning Contractors of America.

ACCA (2009a). (2009). ACCA Standard 9: HVAC Quality Installation Verification Protocols. Arlington, VA: Air Conditioning Contractors of America.

ACCA (2009b). Manual D: Residential Duct Systems, Third Edition. Arlington, VA: Air Conditioning Contractors of America.

Arena, L. (2010). "Guidelines for Complying with BPI's Technical Standards for the Air Conditioning and Heat Pump Professional." Norwalk, CT: Steven Winter Associates, Inc. http://www.clarkcountynv.gov/Depts/admin_services/comresmgmt/Documents/NSP/Guidelines for_Complying_with_BPI_AC_Tech_Standards_09232010.pdf. Accessed July 28, 2011.

ASHRAE (2004). ANSI/ASHRAE Standard 152: Method of Test for Determining the Design and Seasonal Efficiencies of Residential Thermal Distribution Systems. Atlanta, GA: American Society of Heating, Refrigeration, and Air Conditioning Engineers.

ASHRAE (2009). 2009 ASHRAE Handbook: Fundamentals. Atlanta, GA: American Society of Heating, Refrigeration, and Air Conditioning Engineers.

BPI (2003). Technical Standards for the Air Conditioning and Heat Pump Professional. Malta, NY: Building Performance Institute. http://bpi.org/Web\%20Download/BPI\%20Standards/Air\%20Conditioning\%20and\%20Heat\%20 Pump\%20Professional\%20Final\%202003.pdf. Accessed July 28, 2011.

CARB (2009). "Why Right Size?” Norwalk, CT: Steven Winter Associates, Inc. http://www.carb-swa.com/articles/guidelines/ Why\%20to\%20Rightsize\%20Guide.pdf. Accessed July 28, 2011.

Continental Control Systems. (2011). "Measurement Errors Due to CT Phase Shift." http://www.ccontrolsys.com/w/Measurement_Errors_Due to_CT_Phase_Shift. Accessed December 4, 2011.

Hohman, J. (2009). HVACR 201. Clifton Park, NY: Delmar Cengage Learning.

Hohman, J. (2010). HVACR 301. Clifton Park, NY: Delmar Cengage Learning.

Krigger, J., Dorsi, C. (2006). Saturn Mechanical Systems Field Guide. Helena, MT: Saturn Resource Management, Inc. 
Krigger, J., Dorsi, C. (2008). Home Performance Specifications for Warm Climates. Helena, MT: Saturn Resource Management, Inc.

NREL (2011). "National Residential Efficiency Measures Database: Retrofit Measures for Duct Sealing." National Renewable Energy Laboratory.

http://www.nrel.gov/ap/retrofits/measures.cfm?gId=2\&ctId=17. Accessed October 4, 2011.

Medina, J. (2011). "In Nevada, a City Hall Is a Reminder of Flush Days.” New York Times. http://www.nytimes.com/2011/11/20/us/in-north-las-vegas-new-city-hall-is-a-reminder-of-flushdays.html?pagewanted=all. Accessed December 1, 2011.

Moravek, J. (2009). HVACR 101. Clifton Park, NY: Delmar Cengage Learning.

Polly, B.; Gestwick, M.; Bianchi, M.; Anderson, R.; Horowitz, S.; Christensen, C.; Judkoff, R. (2011). "A Method for Determining Optimal Residential Energy Efficiency Retrofit Packages." Golden, CO: National Renewable Energy Laboratory.

Rudd, A. (2006). "Design Process for Sizing: Cooling and Heating System Capacity, Room Air Flows, Trunk and Runout Ducts, and Transfer Air Ducts.” Westford, MA: Building Science Corporation.

Rutkowksi, H. (1995). Manual S, Residential Equipment Selection. Arlington, VA: Air Conditioning Contractors of America.

Rutkowksi, H. (2006). Manual J, Residential Load Calculations, Eighth Edition. Arlington, VA: Air Conditioning Contractors of America.

Wray, C.; Walker, I.; Sherman, M. (2002). "Accuracy of Flow Hoods in Residential Applications." Berkeley, CA: Lawrence Berkeley National Laboratory. 
buildingamerica.gov

\section{U.S. DEPARTMENT OF Energy Efficiency \& ENERCY Renewable Energy}

